Document de Recherche du Laboratoire d'Économie d'Orléans

Working Paper Series, Economic Research Department of the University of Orléans (LEO), France

DR LEO 2019-05

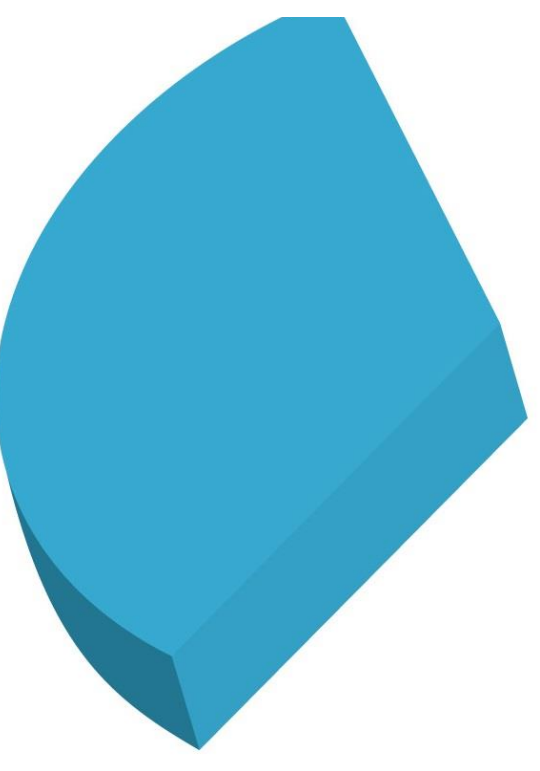

Economic sentiments and
money demand stability in the CEECs

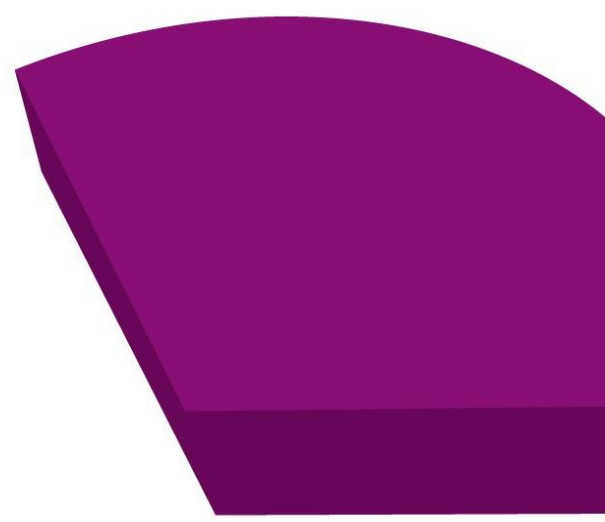

Valentina-loana MERA

Monica loana POP SILAGHI

Camélia TURCU

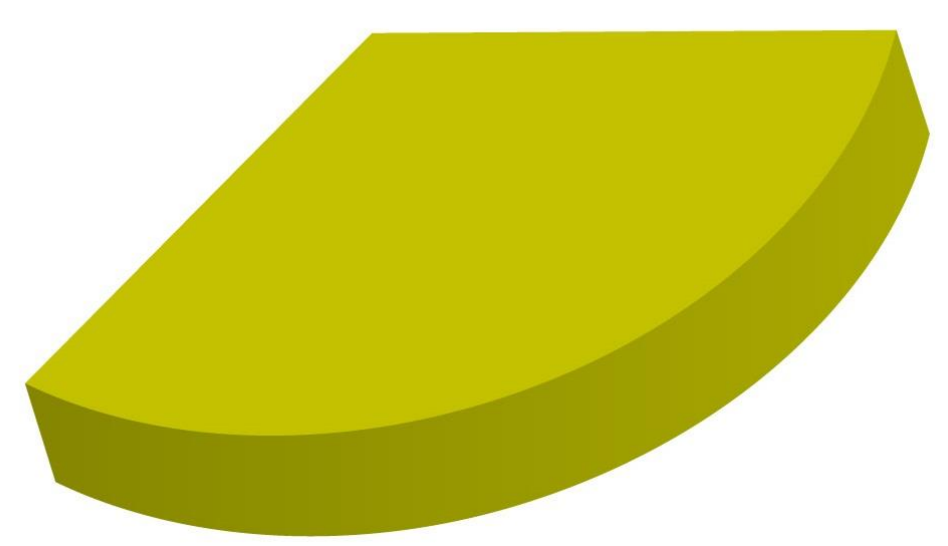

Mise en ligne / Online : 23/09/2019 


\title{
Economic sentiments and money demand stability in the CEECs
}

\author{
Valentina-Ioana MERA*, Monica Ioana POP SILAGHI* and Camélia TURCU ${ }^{\circ}$ \\ * Babeş-Bolyai University, Teodor Mihali Street, nr. 58-60, Cluj-Napoca 400591, Romania \\ ${ }^{\circ}$ Univ. Orléans, LEO, CNRS
}

\begin{abstract}
This paper aims at building a money demand function that takes account of the heterogeneities of the Central and Eastern European Countries (CEECs) in the context of the European integration. We extend the traditional specification of money demand to capture the effects of a change in agents' expectations regarding the dynamics of economic activity. The traditional determinants of the demand for money (real GDP, interest rate, inflation rate) are found to be significant and have the expected sign. Above this, we also find that the role of economic sentiments - captured through the European sentiment indicator (ESI) - is significant in explaining the money demand: consumers' and investors' gloomy expectations concerning future economic developments trigger an increase in the domestic money demand, due to precautionary reasons. Our results also suggest that a currency substitution effect, against both euro and USD, is present in the CEECs.
\end{abstract}

Keywords: money demand, economic sentiments, CEECs, Dynamic OLS

JEL Codes: E41, E52

${ }^{1}$ Univ. Orleans, CNRS, LEO, FRE 2014. Rue de Blois, 45067 Orléans, France. Email address (corresponding author): camelia.turcu@univ-orleans.fr 


\section{Introduction}

In 2017, in the State of the Union Address, the President of the European Commission, JeanClaude Juncker stressed, among other topics, that the euro has to become the single currency of all the EU (European Union) countries: "If we want the euro to unite rather than divide our continent, then it should be more than the currency of a select group of countries. The euro is meant to be the single currency of the European Union as a whole." Even though a clear monetary integration agenda is not yet established for the non-eurozone countries, the above statement underlines the necessity that all EU countries that took the commitment to adopt the euro in the near future, go further on this path. Within this framework, the study of the money demand in Central and Eastern European Countries (CEECs) becomes a key issue.

After joining the EU, six of the CEECs (namely: Bulgaria, Croatia, Czech Republic, Hungary, Poland and Romania) have committed themselves towards adopting the single currency as soon as the Maastricht convergence criteria are fulfilled. From a monetary policy perspective, adopting the euro means, for these countries, that they will give up to their monetary autonomy and follow the decisions of the European Central Bank (ECB). The role of the monetary autonomy in the CEECs that kept their monetary independence was analyzed by the IMF (2015). This analysis shows that monetary tightening and exchange rate appreciation helped these countries to offset the credit boom in the mid-2000s and support the domestic demand in the aftermath of the 2008-2009 financial crisis, through monetary easing (IMF, 2015). The estimated coefficients for the money demand determinants can offer interesting insights regarding the appropriateness of adopting the single currency, according to Fidrmuc (2009). He argues that if the estimated parameters of money demand are close to those in developed countries, this may create good preconditions for euro adoption.

Fifteen years ago, the perspective of euro adoption was widely seen, in general, as a positive factor. From the perspective of consumers or investors, the euro area membership was considered as a guarantee for macroeconomic stability and reduced risk. However, over the period 2010-2013 there was a decline in terms of the reputational value of the euro area membership among the new EU member states (IMF, 2015). This hypothesis is strengthened by the perceptions and expectations of the citizens coming from the six CEECs that are expected to join the euro area in the near future. The general opinion about the euro adoption is mixed (Flash Eurobarometer, 2017). In Bulgaria, Romania, Hungary and Croatia, the share of those who are in favor of the euro adoption is higher than the one of those who are against, 
while in the Czech Republic and Poland, the situation is reversed ${ }^{2}$. Nevertheless, only one out of five respondents considers that their country is ready to join the euro area (Flash Eurobarometer, 2017, p.22). This idea gives rise to a further question concerning the money demand stability: can we consider that the stability of the demand for money is influenced by the attitude regarding the economic and monetary integration? Within this framework, it is also interesting to see how the demand for money in countries candidate at the EU integration has evolved. In this respect, we will pay attention to the case of Turkey and Macedonia, candidates to the EU integration.

The objective of this paper is to assess whether the perspective of economic and monetary integration and the changing composition of the currency demand has influenced the stability of the money demand function in the CEECs. We do not search to respond to the question of whether the CEECs are prepared to adopt the single currency, we simply aim to investigate to what extent the degree of integration has influenced the demand for domestic money. More specifically, we want to assess the characteristics of the money demand function in the case of the CEECs and to investigate if it has been influenced by a specific set of determinants, besides the traditional ones.

In this perspective, we aim at analyzing in particular whether the economic sentiments have played a role for money demand. We suppose that if domestic agents and consumers consider that their country is strongly influenced by the interactions with the rest of the world, they revise their expectations regarding the future economic situation in their country, according to what they observe abroad. In the context of the European integration, the CEECs become more and more connected with the euro area (some channels are detailed in the following section) and with the EU members. As a consequence, domestic economic agents might tie their actions and decisions to the observed economic and political situation of their home country, but also to what happens in the euro area or in the EU in general. Since the 1990s on, the CEECs have followed a common trend, first, during the transition period and, second, in line with their common objective of European integration. In order to achieve the latter (i.e. seen in the '90 as a long-term objective), the CEECs have also adopted country specific measures.

\footnotetext{
${ }^{2}$ While in Romania 64\% of the respondents are in favor of introducing the euro, in the Czech Republic only $29 \%$ think the same.
} 
To test the above stated hypothesis on money demand in the CEECs, we employ a panel framework and cointegration techniques à la Pedroni (1999, 2004). Long run panel estimates are generated using the panel dynamic ordinary least squares (DOLS) developed by Kao and Chiang (2000). This method has the advantage to account for both cross-sectional dependence between individuals (in line with the common shocks identified above) and individual heterogeneity (in the presence of country-specific policy measures). We will focus our attention on a sample of CEECs consisting of six European Union members that have not yet joined the euro area and of two official EU candidates.

This paper contributes to the existing money demand literature in several ways. First, it assesses the characteristics of money demand in the CEECs from the perspective of the European integration. Second, a measure of the economic sentiments is introduced in the money demand function in order to capture the expectations and the anticipations of the consumers and investors in the light of the European and monetary integration. This is meant to capture a certain contagion effect in terms of expectations. Moreover, by including in the sample both EU and non-EU countries, we incorporate, in the function, agents' perceptions and anticipations in the pre-accession period to the European Union as well as to the euro area.

With these objectives set, the remainder of the paper is structured as follows. Section 2 is dedicated to the review of the papers related to the money demand analysis, with a special focus on the countries belonging to Central and Eastern Europe. In Section 3, we describe the modeling framework and the data that will be used to test the theoretical hypotheses. The empirical strategy and the results are presented in Section 4. Section 5 describes the robustness checks. The conclusions and policy implications are provided in Section 6. Lastly, a detailed description of the sample, of the variables and of the unit root tests is presented in the Appendix.

\section{Literature review}

The stability of money demand has been addressed in a large number of studies, being often associated with the selection of specific monetary and economic country characteristics. Among others, Dreger et al. (2007) and Bahmani and Kutan (2010) link the stability of money demand to the monetary regime choice of the CEECs. Bahmani and Kutan (2010) argue, analyzing the CEECs as well, that a stable money demand function is a valuable indicator to determine the degree to which these countries are prepared to use monetary aggregates to 
conduct monetary policy. If the monetary policy is based on monetary aggregates targeting, the objective of fulfilling the Maastricht criteria will be feasible only if the money demand function is stable (ECB Monthly Bulletin, 2011). According to this view, the CEECs in our sample adopted monetary policy regimes based either on inflation targeting or exchange rate targeting. This is due to the fact that the demand for money is considered to be unstable in an uncertain economic environment (as in the 90s transition period).

To underline the role of money demand in the CEECs in the context of European integration, several arguments can be put forward. First, as the monetary policy is the first pillar of the European Central Bank's strategy, the perspective of euro adoption puts forward the key role of this policy in the CEECs on their integration path. In the context of a policy aimed at maintaining price stability, the monetary developments are analyzed in comparison to the evolution of prices, income or interest rates, so as to assess the driving forces that make them deviate from the expected long-term relation (ECB Monthly Bulletin, 2011). Monetary developments are also relevant for the countries in our sample due to their impact on price evolution. Using the experience of 46 advanced and emerging economies on the time span 1950-2011, Gertler and Hofmann (2016) show that there is a stronger connection between inflation and money in emerging countries compared to advanced countries. Moreover, the inflation response to a monetary shock is found to be stronger in highly dollarized economies, according to the empirical findings of Levy-Yeyati and Rey (2006).

Second, there are different channels through which the CEECs are connected with the euro area, as a result of the European integration. Oros and Romocea-Turcu (2009) analyze the channels of monetary policy transmission from 1998 to 2006/2007 in six CEECs. The transmission mechanism in Czech Republic and Romania is found to be more closely related to the one of the euro area, being dominated by the interest rate, while in Hungary and Poland, where the dominant channel of transmission is the exchange rate, the giving up of this monetary policy instrument would be more costly. Moder (2017) analyze, for the more recent period, the impact of the unconventional ECB policies in eight south-eastern European countries, and identifies exports as being the main transmission channel for international spillovers. Domestic prices are affected by an expansionary unconventional monetary policy and the effect is greater in half of the countries, compared to the euro area. The integration is strongly supported by the financial channel, as a high proportion of foreign investments in these countries originates from the euro area. This, in addition to the presence of foreign banks which operate in CEECs countries, facilitates the substitution between the domestic 
currencies and the euro. A key indicator of this substitutability is the high proportion of foreign currency denominated loans to total loans ${ }^{3}$. The widespread deposit euroisation may be the result of the distrust in the stability of the national currency (Brown and Stix, 2014), which in turn is the result of the unfavorable assessment of the political and institutional factors. However, we can also argue that this causal direction might be reversed, if the perspective of euro adoption becomes a certainty.

In reality, this form of substitutability is sometimes perceived as limiting the effectiveness of the monetary policy. Within this framework, several authors assess the role of the euroisation and financial development in the context of the monetary policy. For example, Georgiadis and Mehl (2016) find that, as a result of the financial globalization, economies have become increasingly net long in foreign currency: hence, the monetary policy effectiveness was amplified by the exchange rate channel. In contrast to the previous results, Ma and Lin (2016) find a negative strong correlation between financial development and the effects of monetary policy, on inflation and output. Beckmann et al. (2011) study the substitution between domestic and foreign loans in Czech Republic, Hungary, Poland and Slovak Republic. Their empirical results show that the two are close substitutes: this affects the central bank's ability to impose credit restrictions. Moreover, using data originating from surveys on households from Central, Eastern and Southeastern Europe (CESSE) throughout the 2007-2010 period, the authors show that the demand for foreign currency loans was not too much affected by the foreign currency depreciation associated to the crisis.

A recent, but rather scarce literature addresses the topic of money demand in the CEECs, either at country level (Buch (2001), Komárek and Melecky (2004), Hsieh and Hsing (2009), Vladova and Yanchev (2015)) or at cross-country level (Dreger et al. (2007), Dritsaki and Dritsaki (2012), Škare et al. (2016)). In an error-correction framework, the long-run elasticities of money demand match the theoretical expectations for Hungary and Poland, at the beginning of transition period (Buch 2001). Dritsaki and Dritsaki (2012) confirm the existence of a cointegration relationship between real money and two explanatory variables: real GDP and nominal short-term interest rate, in Romania and Bulgaria.

\footnotetext{
3 The proportion of foreign currency denominated loans exceeds $60 \%$ in Croatia and $40 \%$ in FYR Macedonia from 2006 onwards, but it is decreasing slowly. In contrast, in Turkey the trend is upward, and it increases from around $40 \%$ in 2011 to over 50\% in 2016. In Czech Republic and Poland the proportion is lower, fluctuating only slightly between $15-25 \%$.
} 
Some of the studies based on the CEECs focus on the role of foreign exchange in determining the currency substitution between the domestic and foreign currency. Selçuk (2003) identifies the foreign currency to be a close substitute for the domestic currency by producing liquidity services in a sample of countries including Czech Republic, Hungary, Poland and Turkey, among others. Using panel data on the period 1995-2004, Dreger et al. (2007) underline the role of the exchange rate against USD in ten countries that joined EU in May 2004, as money and its determinants are cointegrated only when this variable is included in the specification. Over a similar time span, Fidrmuc (2009) finds a small and significant impact of the exchange rate against euro in explaining the money demand in six CEECs. In addition, his results are in favor of an important capital substitution in these countries.

We aim at filling a gap in the empirical literature on money demand by assessing the role of economic agents' perceptions and sentiments in explaining the money demand in the CEECs, the context of the transformations taking place in these countries on the way towards European integration. Therefore, we use the experience of eight CEECs that are part of this process, either on their way towards economic integration or towards monetary integration. To the best of our knowledge, the only paper that captures the presence of uncertainty in the money demand function for the CEECs is the one of Bahmani-Oskooee et al. (2013). They augment the money demand function by including two computed GARCH measures for monetary and economic uncertainty. However, they do not specifically account for the perceived uncertainty in the context of European integration, as they focus only on the transition period, and do not consider the EU candidates.

Therefore, our contribution to the existing money demand empirical literature is the following: we focus on the CEECs in a panel framework, assessing how the path towards economic or monetary integration has influenced the stability of money demand. We do this by including a measure of economic sentiments in the money demand specification, a measure that aims at capturing the economic agents' perception regarding future economic developments. This could lead to valuable insights from a regional perspective, given that these countries are more and more connected with the EU or euro area. If domestic agents in the analyzed countries incorporate this connection in their domestic decisions, they can revise their expectations, not only as a result of national developments, but also as a consequence of the economic changes they observe at the European level. 


\section{Modeling framework and data}

The stability of money demand is investigated for a sample of eight Central and Eastern European countries. Data is collected on a quarterly basis for a period spanning from 2008Q1 to 2017Q1. The countries belong to two categories. The first one comprises the countries that joined the EU in 2004 (the Czech Republic, Hungary, Poland), 2007 (Bulgaria and Romania) and in 2013 (Croatia) and are expected to join the euro area in order to complete their European integration. The second one includes two official EU candidates, namely FYR Macedonia and Turkey. This second sample is restricted solely to these two countries due to the data availability for the European Sentiment Indicator ${ }^{4}$. Our initial purpose was to capture the differences between the two stages of integration (European economic integration and European monetary integration). This would have lead to interesting conclusions related to coefficients magnitude. Since the data on the other three official EU candidate countries (Albania, Serbia and Montenegro) is not available, we decided to run our estimations using only the data on Turkey and Macedonia. For a detailed description of the sample see Appendix 1.

To assess the characteristics of money demand function in the CEECs, our paper uses the model developed by Leventakis (1993). The function of money demand is derived from a two-country portfolio balance model. In this formulation, the demand for domestic currency comes from both domestic residents and non-residents. As a result, domestic currency has three types of substitutes: foreign currency, domestic and foreign bonds. The foreign currency is considered to bring liquidity for the domestic country. Specifically, in our sample, the foreign currency consists mainly of the euro and USD, as these are the main currencies that bring liquidity for the CEECs. The market for domestic real money clears when the sum of the demand coming from both residents and non-residents equals the domestic money supply.

Following Leventakis (1993), the demand for real money is defined as a function of real income $(\mathrm{Y})$, interest rate $(\mathrm{R})$, inflation rate $(\pi)$ and exchange rate $(\mathrm{EX})$. We also include a variable that captures consumers and investors perception and expectations - ESI - (described below):

$$
\ln (M / P)_{i t}=\alpha_{i}+\beta_{1} \ln Y_{i t}+\beta_{2} R_{i t}+\beta_{3} \pi_{i t}+\beta_{4} \ln E X_{i t}+\beta_{5} \ln E S I_{i t}+\varepsilon_{i t}
$$

\footnotetext{
${ }^{4}$ The sample is restricted to eight countries, because data are missing or are incomplete for the other three official EU candidate countries: for Albania there is a complete lack of data; for Montenegro data is available only from 2012Q2 and for Serbia only from 2013Q2.
} 
where $\alpha_{i}$ is a positive constant, $\beta_{i}(\mathrm{i}=1, \ldots 5)$ are the long term elasticities and $\varepsilon_{i t}$ denotes the estimated residuals. A broad monetary aggregate was used to quantify money demand (the real M2 - where the nominal money stock was deflated by CPI). Our choice is dictated by the purpose of focusing on a wider range of assets that could render benefits for the asset holders' portfolio, in addition to the transactional role of money. According to Sriram (1999)' a broader measure of money gives more relevance to the asset motives of holding money and also empirical evidence shows that there is a stronger association of inflation rate with broad money, than with narrow money (Gertler and Hoffman, 2016)

The money demand function used in this paper includes a scale variable and opportunity cost variables. The scale variable is the real GDP, in 2010 constant prices. Since we use a broader monetary aggregate, that comprises interest bearing deposits, a long-term interest rate would be preferable. However, data availability imposes restrictions on this requirement and we choose to use the deposit rate as a proxy for the interest rate. The inflation rate is computed based on consumer price index $(2010=100 \%)$. Two exchange rate series are included to account for the currency substitution effect: the nominal exchange rate against euro and the nominal exchange euro against USD. By construction, an increase in the nominal exchange rate against euro and USD translates a depreciation of the domestic currency. All variables, except interest rate, are expressed in logarithms. The series for real money and real GDP were seasonally adjusted. The variables and the data sources are presented in details in Appendix 2. Several descriptive statistics are reported in Table 1 for the interest rate, inflation rate and the European sentiment indicator.

\begin{tabular}{lcrrr}
\hline \multicolumn{4}{l}{ Table 1- Descriptive statistics } \\
\hline Variable & Obs. & Mean & Std. dev. & \multicolumn{1}{c}{ Median } \\
\hline $\mathrm{R}$ & 296 & 4.873 & 0.295 & 3.11 \\
$\Pi$ & 296 & 0.709 & 0.065 & 0.49 \\
ESI & 296 & 98.288 & 0.542 & 98.315 \\
\hline \multicolumn{5}{c}{ Source: authors' computation }
\end{tabular}

A priori, we expect positive income elasticity and negative domestic interest rate and inflation rate elasticities. The inflation rate is expected to affect negatively the demand for money as it is a measure on the return on holding goods. The sign of $\beta_{4}$ can be both positive or negative, depending on the magnitude of the two opposite effects following depreciation: the substitution effect and the wealth effect. 
The novelty of this paper is that we account empirically for the perceived uncertainty in Central and Eastern European countries in the years preceding euro adoption. The idea that the degree of the uncertainty perceived may affect the share of wealth held as money dates back from Friedman. According to this hypothesis, an increased uncertainty determines a shift towards more liquid assets including money. The precautionary motive is invoked here. We chose to incorporate this effect by means of the European Sentiment Indicator (ESI). This indicator reflects the judgments, expectations and perceptions and the actions of many economic actors. It is constructed as a composite indicator based on the confidence indicators coming from five sectors: industry, services, consumers, construction and retail trade. The values above 100 indicate an above-average economic sentiment, while the values below 100 reflect a below-average perception. Largely speaking, it tracks the overall economic activity, as it aggregates the sector level confidence indicators. If we track the sentiments-expectationsdecisions chain, we would expect an above average value of this indicator to be a sign of a favorable assessment of the economic activity. In other words, when agents have positive expectations about the future or their confidence in the overall economic activity is increased, we consider this to be the result of a perception based on lower risk, insecurity or uncertainty.

Regarding the impact of the indicator used as a proxy for the perceived uncertainty, a priori we can expect both positive and negative coefficients. By construction, a decrease in the European sentiment indicator reflects a less favorable assessment of the future development of the economy. We hypothesize that an optimistic (or pessimistic) assessment incorporates agents' perceptions and expectations, that are formed as a result of what they anticipate regarding the lack (or the presence) of uncertainty. This could determine two opposite effects on money demand. First, it can increase the demand for money for precautionary reasons, as economic uncertainty makes economic agents more pessimistic about the future of the economy and offers an incentive to save more. This view supports Friedman's (1987) statement regarding the positive effect of an increased uncertainty on money demand, due to precautionary reasons. Second, it can decrease the demand for real money as agents choose to rebalance their portfolio by increasing the demand for real assets. Choi and Oh (2003) argue that the magnitude of the two effects (i.e. substitution effect and precautionary effect) depends on the degree of substitutability between money and other assets considered less volatile.

Figure 1 depicts the evolution of the European Sentiment Indicator in the countries included in our analysis, using two sub-samples: the countries that belong to the European Union (Figure 1a) and the official EU candidate countries (Figure 1b). We use country level values 
of this indicator in order to account for the overall confidence in each country. As Figure 1a shows, the evolution of the European sentiment indicator in the EU-countries is similar among the countries regarding its upward or downward fluctuation, albeit with some differences in magnitude. Starting with 2015, the value of the indicator is above 100 in Bulgaria, Hungary, Croatia, Czech Republic and Romania fact pointing towards a favorable assessment of the economic situation in the region. Only in Poland the values remain below the average for most of the period. In Turkey and FYR Macedonia, the values indicate a more pessimistic view regarding the economic development and this trend is maintained also in the recent years.
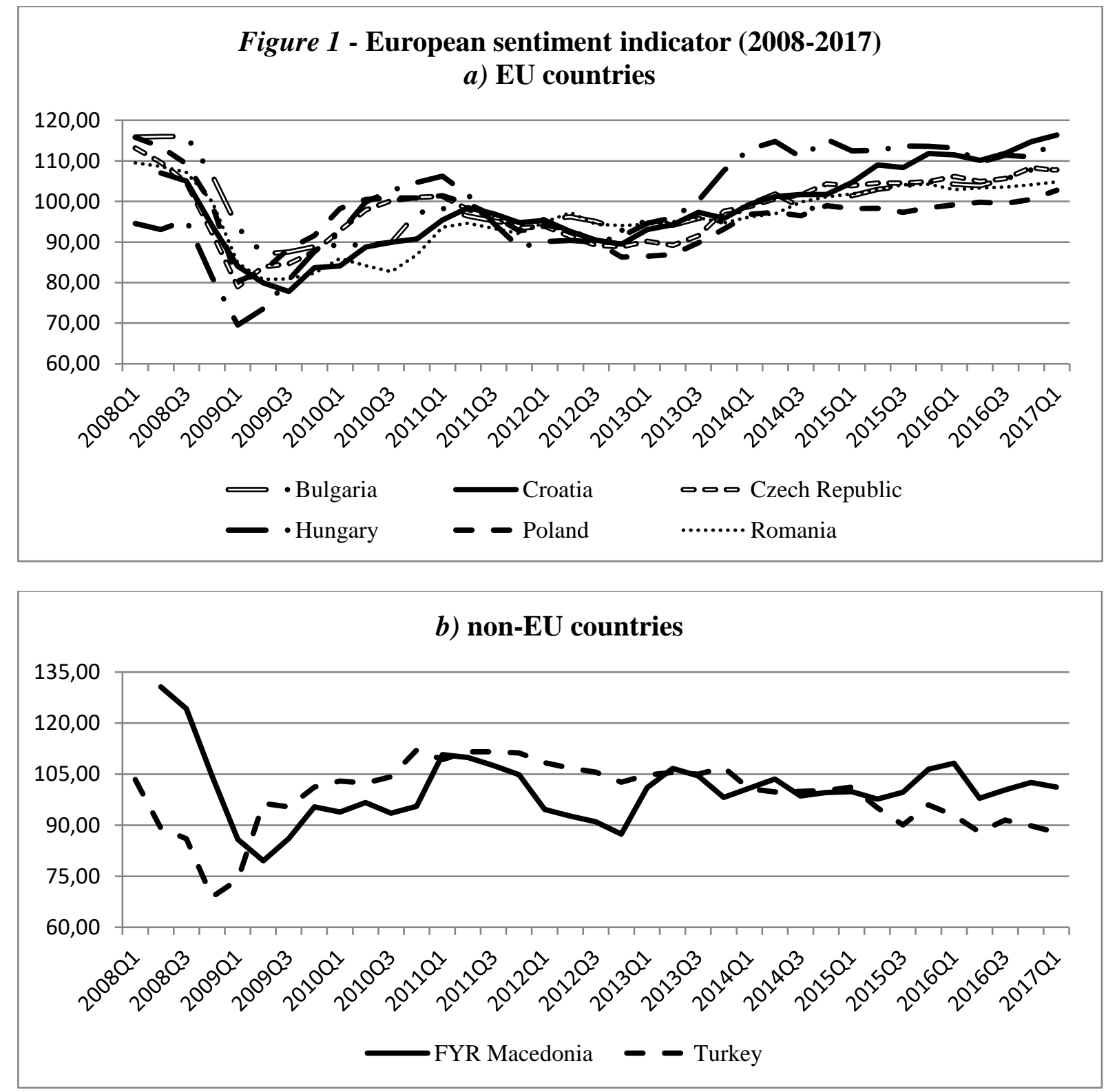

Source: European Commission Surveys database. 
The fact that within these countries there are similarities regarding the level of integration is expected to bring them closer in terms of monetary policy characteristics. The common factors among the countries in our sample are the regulatory changes and the substantial financial sector development they experienced in the last twenty years. Hence, we could expect that they have followed a common trend over the analyzed period. However, the shocks may not be distributed uniformly across these countries. Therefore, the sample does not represent a fully homogenous group. From a simple cross-country comparison, notable differences can be found with respect to the monetary policy and exchange rate regime they adopted. Appendix 3 summarizes the main features regarding the monetary policy regime and the exchange rate strategy.

The three countries that joined EU in 2004 (the Czech Republic, Hungary and Poland) and those that became EU members later on (Bulgaria and Romania in 2007 and Croatia in 2013), are expected to adopt the euro in the near future. Czech Republic, Hungary, Poland and Romania adopted a monetary policy regime based on inflation targeting and allow the exchange rate to float. Bulgaria and Croatia have a less autonomous monetary policy, as they tied their currency to the euro. In Bulgaria, a currency board arrangement has been in place since 1997 and the exchange rate of the Bulgarian Lev is fixed against euro. Croatia targets the nominal exchange rate of Kuna against euro.

As the purpose of our analysis is to study not only the perspective of monetary integration with respect to the euro area, but also the perspective of the economic integration within the European Union, two official candidates to the EU are also considered, as stated in previous sections. These countries have different monetary policy regimes: while Turkey had adopted an inflation targeting regime, Macedonia FYR is targeting the nominal exchange rate against euro.

\section{Empirical analysis: econometric strategy and results}

\section{Panel unit root tests}

The first step before empirically testing the long-run money demand is to investigate the properties of our panel data. The dimensions and the properties of our panel suggest the use of Levin, Lin and Chu (2002), Im, Pesaran and Shin (2003) and Fisher-type tests (Maddala and $\mathrm{Wu}, 1999)$ in order to test the stationarity of the series. 
Levin, Lin and Chu (2002) proposed unit root tests for panels of moderate size. The panel unit-root tests they propose allow for individual-specific intercepts and time trends. The unit root test is in their case based on a t-statistic obtained from a pooled cross-section time series data. The null hypothesis that each individual time series contains a unit root is tested against the alternative that each time series is stationary. The main limitations of the unit root test proposed by Levin, Lin and Chu (2002) is that when cross sectional correlation is present this test is not applicable, as it is based on the assumption of independence across individuals.

Im, Pesaran and Shin (2003) address the homogeneity issue in panel unit root testing. The procedure for dynamic heterogeneous panels proposed by Im, Pesaran et Shin (2003) is based on averaging individual ADF unit root tests statistics. The null hypothesis of the unit root test is $\mathrm{H}_{0}: \beta_{\mathrm{i}}=0$ for all $\mathrm{i}$-individuals, with the alternative that $\mathrm{H}_{1}: \beta_{\mathrm{i}}<0$. This formulation allows for $\beta_{\mathrm{i}}$ to differ between individuals, which is a less restrictive condition in comparison to the hypothesis of Levin, Lin and Chu (2002) in which all $\beta_{\mathrm{i}}$ are restricted to $\beta$ ( $\beta_{\mathrm{i}}=\beta$ for all $\mathrm{i}=1,2, \ldots, \mathrm{N})$. Hence, instead of pooling the data, individual unit root tests are computed for each one of the $\mathrm{N}$ cross-section units and then they are averaged (Maddala and $\mathrm{Wu}, 1999$ ). When the null hypothesis is rejected, this does not necessarily imply that it is rejected for all the cross-sectional units, but for a large majority.

The Fisher-type tests combine the p-values from a unit root test applied to each group in the panel using the four methods proposed by Choi (2001). Different lag lengths in the individual regressions are allowed even when the ADF test is used (Maddala and $\mathrm{Wu}, 1999$ ). The null hypothesis to be tested is that all the panels contain a unit root. Using Monte Carlo simulation, Maddala and $\mathrm{Wu}$ (1999) shows that when the errors in different cross-section units are crosscorrelated, the Fisher test performs better. Moreover, when $\mathrm{T}$ is large and $\mathrm{N}$ is not very large, the size distortion with the Fisher-test is small.

The countries in our dataset have experienced during the analyzed period structural changes, for catching-up with the former western European countries. In this context, we would expect a clear trend pattern in the evolution of gross domestic product and of monetary variables. To account for this effect, the tests are performed both with and without a trend. Results of the panel unit root tests in both level and first difference are provided in Appendix 4. The results for real money, real income and interest rate indicate that there is a unit-root in the series. For the inflation rate, exchange rates and European sentiment indicator the unit root tests give mixed results for the variables in levels. Therefore, we can conclude that all variables are 
stationary in first differences, which allows us to test for cointegration among these variables and to estimate the money demand function.

\section{Cointegration}

Based on the above elements regarding the properties of our data sample, we test the existence of cointegration in the panel framework using the panel cointegration tests of Pedroni (1999, 2004). He proposed a set of panel cointegration tests for non-stationary heterogenous panels with a large time dimension $\mathrm{T}$ and medium to large $\mathrm{N}$. The test for cointegration can be applied also for unbalanced panels. It uses seven test statistics to test the null of no cointegration in non-stationary panels (Neal, 2014).

The tests statistics allow for panel heterogeneity both in the short-run dynamics and long-run slope and intercept coefficients. The common time dummies can be included so as to account for the cross-sectional dependency. The seven test statistics introduced by Pedroni (1999, 2004) are residual based tests and are then adjusted so that they are distributed as $\mathrm{N}(0,1)$ under the null hypothesis. They can be divided into two categories: group mean statistics and panel statistics. The statistics from the first category are based on the between dimension approach average the results on individual test statistic. The panel statistics pool the autoregressive coefficients across different countries for the unit root tests on the estimated residuals and are based on the within dimension approach.

\begin{tabular}{|c|c|c|c|c|}
\hline \multicolumn{5}{|c|}{ Table 2- Pedroni $(1999,2004)$ Panel Cointegration Tests } \\
\hline Model & Model 1 & Model 2 & Model 3 & Model 4 \\
\hline \multicolumn{5}{|c|}{ Panel test statistics } \\
\hline Panel v & -1.197 & -0.950 & -0.906 & -0.748 \\
\hline Rho statistic & $2.564 * * *$ & $2.167^{* *}$ & $-2.102 * *$ & $2.092 * *$ \\
\hline t statistic & $1.827 *$ & 1.019 & 0.980 & 0.944 \\
\hline ADF statistic & $2.161^{* *}$ & $2.218^{* *}$ & $2.400 * * *$ & $2.351 * * *$ \\
\hline \multicolumn{5}{|c|}{ Group test statistics } \\
\hline Rho statistic & $3.511 * * *$ & $3.082 * * *$ & $2.927 * * *$ & $2.805^{* * *}$ \\
\hline t statistic & $2.553 * * *$ & 1.628 & 1.440 & 1.323 \\
\hline ADF statistic & 1.356 & $2.623 * * *$ & $2.431 * * *$ & $2.582 * * *$ \\
\hline
\end{tabular}

Notes: 1 ). ***, *** and $*$ reject the null of no cointegration at $1 \%, 5 \%$ and $10 \%$. The statistics are distributed as $\mathrm{N}(0,1)$. The common time dummies and a linear time trend are included. The number of lags is determined based on AIC. The long-run variance of the residuals is computed through the Newey-West heteroskedasticity and autocorrelation-consistent method with a Bartlett kernel for which the maximum lag length is selected as $4(T / 100)^{2} \%$. 2) The panel includes Bulgaria, Croatia, The Czech Republic, Hungary, FYR Macedonia, Poland, Romania and Turkey.

Source: authors' computation 
The test results related to cointegration are provided in Table 2. The cointegration was tested separately for each model used in the estimation, models that include one at a time the exchange rate against euro (Model 1), against USD (Model 2), the nominal effective exchange rate (Model 3) and the real effective exchange rate (Model 4). The null hypothesis of no cointegration is rejected for all models by at least four out of seven statistics. This is strong evidence in favor of long run cointegration among variables and we can conclude that a long run money demand function exists for our sample.

\section{Dynamic OLS estimation of money demand}

Once cointegration was confirmed in the previous section ${ }^{5}$, the long run money demand can be estimated empirically. The panel DOLS estimator proposed by Kao and Chiang (2000) provides more precise estimations than the single-equation estimator, and it is fully parametric (Mark and Sul, 2003). Kao and Chiang (2000) suggest that the DOLS estimator may be more promising than OLS and Fully Modified OLS (FMOLS) estimators in estimating cointegration in a panel framework, as it works better in both homogenous and heterogenous panels.

The Dynamic OLS estimator was first introduced by Saikkonen (1991) and Stock and Watson (1993) and extended by Mark and Sul (2003) to a panel framework. The results of the MonteCarlo simulation conducted in the paper of Mark and Sul (2003) prove that panel DOLS provides more precise estimates than single-equation DOLS. If, from an empirical point of view, the single equation cointegration estimates can be sensitive to the time span and selected individuals, panel DOLS performs better in offering more precise estimations.

This methodology uses the past (lags) and future (leads) values of the differenced explanatory variables as regressors, in order to account for the endogeneity. The DOLS estimator for the panel is obtained by running the following regression (Kao and Chiang, 2000):

$$
y_{i t}=\alpha_{i}+\gamma^{\prime} x_{i t}+\sum_{j=-p_{i}}^{p_{i}} \delta_{i j}^{\prime} \Delta x_{i, t+j}+u_{i t}
$$

in which $\mathrm{y}_{\mathrm{it}}$ is the dependent variable, $\mathrm{x}_{\mathrm{it}}$ is a vector of $\mathrm{k}$ independent variables and $\Delta x_{i, t+j}$ represents a vector of leads and lags of the first differences of the $x_{i t}$ variables. In this form of the specification, the cointegration vector is homogenous across individuals, being equal to $1-\gamma^{\prime}$. The error term $u_{i t}$ is independent across individuals, but may be dependent across $t$.

\footnotetext{
${ }^{5}$ The presence of cross-correlation patterns was investigated through the lens of the cross-sectional dependence (CD) test of Pesaran (2004): it suggests that cross-sectional units are independenly distributed.
} 
Below, we start by estimating the money demand function defined in equation (1) using DOLS (Kao and Chiang, 2000). The basic models include as explanatory variables: the real GDP, the interest rate, the inflation rate, a proxy for the exchange rate and the European sentiment indicator. Table 3 reports the results obtained using the DOLS estimator for the long run money demand function in two benchmark models: in Model 1 that includes the exchange rate against euro and Model 2 that uses as a proxy the exchange rate against USD.

\begin{tabular}{|c|c|c|c|}
\hline Dependent variable M2 & Model 1 & Model 2 & \\
\hline $\mathrm{Y}$ & $\begin{array}{l}1.019 * * * \\
(0.000)\end{array}$ & $\begin{array}{l}1.007 * * * \\
(0.000)\end{array}$ & \\
\hline $\mathrm{R}$ & $\begin{array}{l}-0.001 * * * \\
(0.000)\end{array}$ & $\begin{array}{l}-0.001 \text { **** } \\
(0.000)\end{array}$ & \\
\hline$\Pi$ & $\begin{array}{l}-0.018^{* * * *} \\
(0.000)\end{array}$ & $\begin{array}{l}-0.034 * * * \\
(0.000)\end{array}$ & \\
\hline EX_EUR & $\begin{array}{l}-0.242 * * * \\
(0.000)\end{array}$ & & \\
\hline EX_USD & & $\begin{array}{l}-0.202 * * * \\
(0.000)\end{array}$ & \\
\hline ESI & $\begin{array}{l}-0.402 * * * \\
(0.000) \\
\end{array}$ & $\begin{array}{l}-0.311^{* * * *} \\
(0.000)\end{array}$ & \\
\hline $\mathrm{T}$ & & & 37 \\
\hline $\mathrm{N}$ & & & 264 \\
\hline
\end{tabular}

Notes: 1 ) $* * *, * *$ and $*$ denotes significance at $1 \%, 5 \%$ and $10 \% .2)$ Two lags and one lead were included in DOLS first differences. 3) All variables, except for the interest rate, are in logs. 4) The panel includes: Bulgaria, Croatia, Czech Republic, Hungary, FYR Macedonia, Poland, Romania, Turkey. Sample period: 2008Q1-2017Q1

All variables have the expected sign and are highly significant. The income elasticity of money demand is significant and slightly above the unit in both specifications. The opportunity cost variables, the interest rate and the inflation rate, carry the expected negative and significant coefficient. As for the role played by the foreign currency on the demand for domestic money, we can observe the presence of the substitution effect suggested by the negative sign of the exchange rate coefficients. The coefficient of the exchange rate against euro is however higher in magnitude than the one of the exchange rate against USD, indicating a greater impact of the exchange rate fluctuations in euro on the domestic demand for money. This result is intuitive given that the process of integration in the European structures is in progress, at different levels, in all the countries of our sample.

The European sentiment indicator has a negative sign in Model 1, as well as in Model 2. Therefore, as the results indicate, a less favorable assessment of the future economic situation -reflected by a less than average value for the ESI- determines a rise of the demand for 
money, due to precautionary reasons. In this case, the precautionary effect dominates the substitution effect and it is quite high in magnitude compared with the other determinants.

\section{Robustness Check}

In the above section, we reported the results of the money demand function including a scale variable, opportunity cost variables and a variable capturing the perception about economic developments in the near future. Our benchmark models included each a bilateral exchange rate of the national currency against either euro or USD, as these currencies represent the main substitutes for domestic money. In this section, we choose to replace these bilateral exchange rate with the nominal effective exchange rate and the real effective exchange rate. For comparison purposes, these models include the effects of a basket of foreign currencies on the domestic money demand. Hence, two models emerge: Model 3 and Model 4.

The results differ slightly with respect to the benchmark models (see Table 4).

Table 4- Panel money demand estimations DOLS-

(with nominal effective exchange rate or real effective exchange rate)

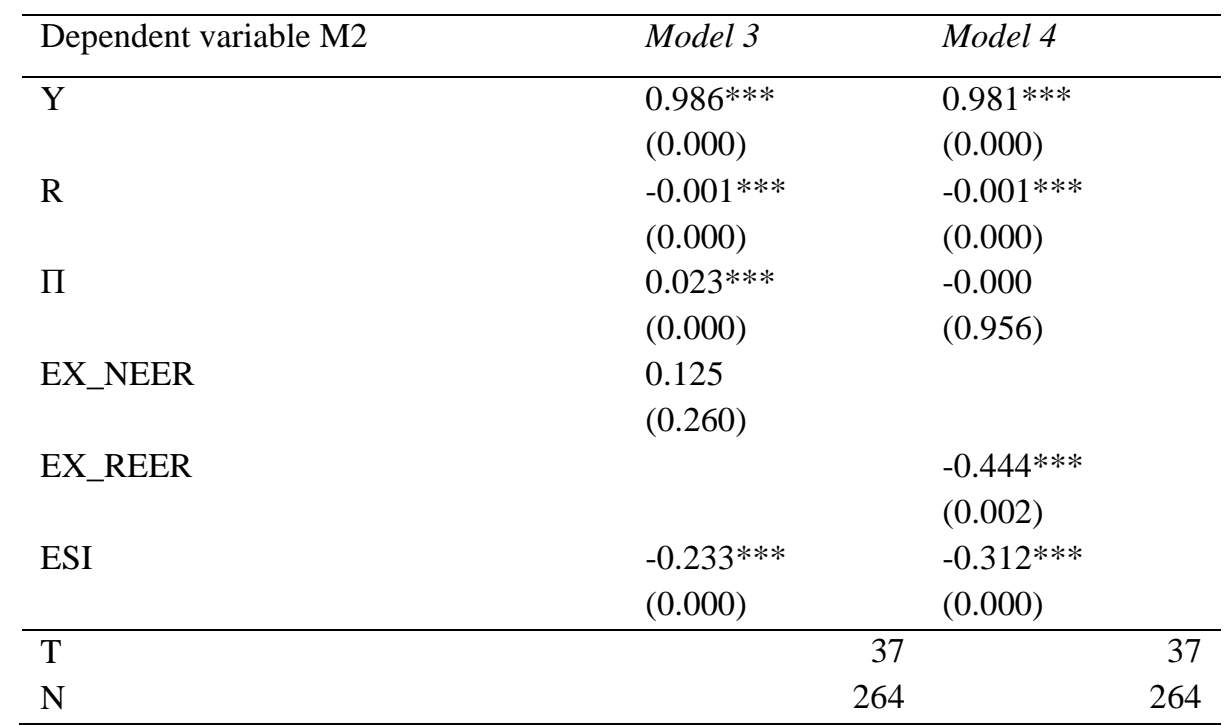

Notes: 1) $* * *, * *$ and $*$ denotes significance at $1 \%, 5 \%$ and $10 \%$. 2) Two lags and one lead were included in DOLS first differences. 3) All variables, except the interest rate, are in logs. 4) The panel includes Bulgaria, Croatia, Czech Republic, Hungary, FYR Macedonia, Poland, Romania and Turkey. Time period: 2008Q12017 Q1.

When the nominal effective exchange rate is included in the estimations, we observe that the exchange rate is no longer significant. Moreover, the sign of the inflation elasticity becomes positive, indicating the presence of money illusion. In contrast, when the real effective exchange rate is included in the model, the results are similar with our benchmark model, even though the inflation rate becomes insignificant. A higher coefficient for the exchange 
rate elasticity is reported, while the impact of the variable that reflects agents' expectations regarding the future economic developments remains robust to the benchmark models and points towards a precautionary effect.

Table 5 and Table 6 report the results of extending our benchmark models by including two major economic events that may have impacted the demand for money. The first one is the Global Financial Crisis of 2008-2010 that covers the first three years under analysis. The second is related to the change of the European Central Bank monetary policy instruments. In order to account for the switch toward unconventional monetary policies, we include a variable that captures the effect of the quantitative easing measures in the euro zone on the CEECs domestic money demand, since 2015 on. A dummy variable is included in the specification in both cases, and the results are reported again for all the four previous models. We can argue that accounting for the effects of the crisis does not significantly change the results (see Table 5).

\begin{tabular}{|c|c|c|c|c|}
\hline Dependent variable M2 & Model 1 & Model 2 & Model 3 & Model 4 \\
\hline $\mathrm{Y}$ & $\begin{array}{l}1.020 * * * \\
(0.000)\end{array}$ & $\begin{array}{l}1.008 * * * \\
(0.000)\end{array}$ & $\begin{array}{l}0.985^{* * * *} \\
(0.000)\end{array}$ & $\begin{array}{l}0.979 * * * \\
(0.000)\end{array}$ \\
\hline $\mathrm{R}$ & $\begin{array}{l}-0.001 * * * \\
(0.000)\end{array}$ & $\begin{array}{l}-0.001 * * * \\
(0.000)\end{array}$ & $\begin{array}{l}-0.001 * * * \\
(0.000)\end{array}$ & $\begin{array}{l}-0.001 * * * \\
(0.000)\end{array}$ \\
\hline$\Pi$ & $\begin{array}{l}-0.019 * * * \\
(0.000)\end{array}$ & $\begin{array}{l}-0.040 * * * \\
(0.000)\end{array}$ & $\begin{array}{l}0.022 * * * \\
(0.000)\end{array}$ & $\begin{array}{l}-0.009 * * \\
(0.036)\end{array}$ \\
\hline EX_EUR & $\begin{array}{l}-0.251 * * * \\
(0.000)\end{array}$ & & & \\
\hline EX_USD & & $\begin{array}{l}-0.216^{* * *} \\
(0.000)\end{array}$ & & \\
\hline EX_NEER & & & $\begin{array}{l}0.070 \\
(0.496)\end{array}$ & \\
\hline EX_REER & & & & $\begin{array}{l}-0.691 * * * \\
(0.000)\end{array}$ \\
\hline ESI & $\begin{array}{l}-0.344 * * * \\
(0.001)\end{array}$ & $\begin{array}{l}-0.304 * * * \\
(0.007)\end{array}$ & $\begin{array}{l}-0.222 * * \\
(0.040)\end{array}$ & $\begin{array}{l}-0.328 * * * \\
(0.003)\end{array}$ \\
\hline D_CRISIS & $\begin{array}{l}4.256 * * * \\
(0.000)\end{array}$ & $\begin{array}{l}3.903 * * * \\
(0.000)\end{array}$ & $\begin{array}{l}1.332 * * * \\
(0.010)\end{array}$ & $\begin{array}{l}0.576 \\
(0.295)\end{array}$ \\
\hline ESI*D_CRISIS & $\begin{array}{l}-0.952 * * * \\
(0.000)\end{array}$ & $\begin{array}{l}-0.878 * * * \\
(0.000)\end{array}$ & $\begin{array}{l}-0.295^{* * * *} \\
(0.009)\end{array}$ & $\begin{array}{l}-0.124 \\
(0.303)\end{array}$ \\
\hline $\mathrm{T}$ & 37 & 37 & 37 & 37 \\
\hline $\mathrm{N}$ & 264 & 264 & 264 & 264 \\
\hline
\end{tabular}

Notes: 1$)^{* * *}, * *$ and $*$ denotes significance at $1 \%, 5 \%$ and $10 \%$. 2) Two lags and one lead were included in DOLS first differences. 3) All variables, except the interest rate, are in logs. 4) The panel includes: Bulgaria, Croatia, Czech Republic, Hungary, FYR Macedonia, Poland, Romania, Turkey. Time period: 2008Q1-2017Q1.

The real GDP, interest rate and inflation rate are all significant and carry the same signs. The European sentiment indicator coefficient is negative and significant in all cases, pointing 
towards a precautionary effect on money demand. The crisis impacts positively the demand for domestic money, except for the case when the real effective exchange rate is included. The result is not surprising given that this period is characterized by increased uncertainty, economic instability and risk, which make money holders increase the demand for real balances due to precautionary reasons. Moreover, we observe a significant marginal effect of the European sentiment in the presence of the crisis in three of the models, indicating a greater impact of the ESI during crisis.

Next, we perform the last robustness check and control for the effect of the quantitative easing (QE) measures adopted by the European Central Bank starting with 2015. Table 6 reports very similar results to previous ones. In all the specifications, the European sentiment indicator remains highly significant and negative.

Table 6- Panel money demand estimations DOLS (including the effects of ECB QE)

\begin{tabular}{|c|c|c|c|c|}
\hline Dependent variable M2 & Model 1 & Model 2 & Model 3 & Model 4 \\
\hline $\mathrm{Y}$ & $\begin{array}{l}1.019 * * * \\
(0.000)\end{array}$ & $\begin{array}{l}1.007 * * * \\
(0.000)\end{array}$ & $\begin{array}{l}0.985 * * * \\
(0.000)\end{array}$ & $\begin{array}{l}0.977 * * * \\
(0.000)\end{array}$ \\
\hline $\mathrm{R}$ & $\begin{array}{l}-0.001 * * * \\
(0.000)\end{array}$ & $\begin{array}{l}-0.001 * * * \\
(0.000)\end{array}$ & $\begin{array}{l}-0.001 * * * \\
(0.000)\end{array}$ & $\begin{array}{l}-0.001 * * * \\
(0.000)\end{array}$ \\
\hline$\pi$ & $\begin{array}{l}-0.018 * * * \\
(0.000)\end{array}$ & $\begin{array}{l}-0.033 * * * \\
(0.000)\end{array}$ & $\begin{array}{l}0.018 * * * \\
(0.000)\end{array}$ & $\begin{array}{l}-0.014 * * * \\
(0.000)\end{array}$ \\
\hline EX_EUR & $\begin{array}{l}-0.241 * * * \\
(0.000)\end{array}$ & & & \\
\hline EX_USD & & $\begin{array}{l}-0.206 * * * \\
(0.000)\end{array}$ & & \\
\hline EX_NEER & & & $\begin{array}{l}0.084 \\
(0.388)\end{array}$ & \\
\hline EX_REER & & & & $\begin{array}{l}-0.830 * * * \\
(0.000)\end{array}$ \\
\hline ESI & $\begin{array}{l}-0.385 * * * \\
(0.000)\end{array}$ & $\begin{array}{l}-0.398 * * * \\
(0.000)\end{array}$ & $\begin{array}{l}-0.122 * * \\
(0.026)\end{array}$ & $\begin{array}{l}-0.150 * * * \\
(0.006)\end{array}$ \\
\hline D_ECB_QE & $\begin{array}{l}-0.009 \\
(0.598)\end{array}$ & $\begin{array}{l}0.038 * * \\
(0.029)\end{array}$ & $\begin{array}{l}-0.058 * * * \\
(0.001)\end{array}$ & $\begin{array}{l}-0.098 * * * \\
(0.000)\end{array}$ \\
\hline $\mathrm{T}$ & 37 & 37 & 37 & 37 \\
\hline $\mathrm{N}$ & 264 & 264 & 264 & 264 \\
\hline
\end{tabular}

Notes: 1) ***, ** and * denotes significance at 1\%,5\% and 10\%. 2) Two lags and one lead were included in DOLS first differences. 3) All variables, except the interest rate, are in logs. 4) The panel includes: Bulgaria, Croatia, Czech Republic, Hungary, FYR Macedonia, Poland, Romania, Turkey. Time period: 2008Q1-2017Q1.

In what follows, we report the results of the panel money demand regressions using different methodological approach. These new results were obtained for all the four models using the Fully-Modified Ordinary Least Squares (FMOLS) estimator proposed by Phillips and Moon (1999) and Pedroni (2000). As the Dynamic Ordinary Least Squares (DOLS) estimator, the Fully Modified Ordinary Least Squares (FMOLS) estimator accounts for endogeneity issues. 
However, in contrast to the DOLS, the second estimator makes corrections for endogeneity and serial correlation to the OLS estimator, nonparametrically (Kao and Chiang, 2000).

The results reported in Table 7 are consistent with our benchmark models in terms of sign and significance of the real GDP, interest rate and inflation rate. By contrast, the currency substitution effect is no longer supported by the data, regardless of the proxy considered for the exchange rate. The assessment of the economic situation has significant impact on money demand only when bilateral exchange rates are considered, and the impact is surprisingly high. These results should be, however, interpreted with caution, as the FMOLS methodology assumes cross section independence (Phillips and Moon, 1999), a requirement that is not fully met in the current analysis as the countries in our sample may be subject to common shocks.

\section{Table 7- Panel money demand estimations FMOLS}

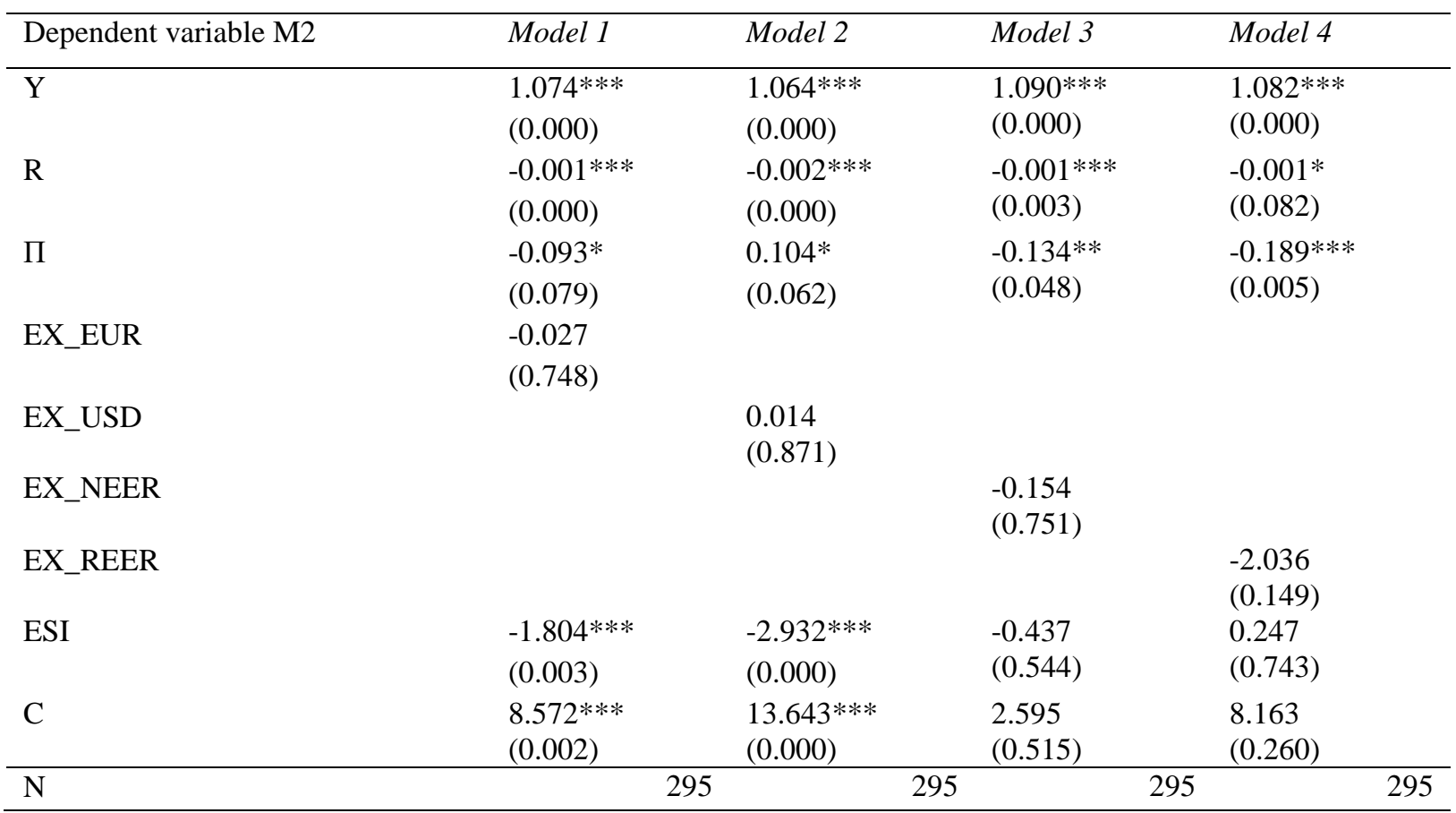

Notes: 1) ***, ** and * denotes significance at $1 \%, 5 \%$ and $10 \%$. 2) All variables, except for the interest rate, are in logs. 3) The panel includes: Bulgaria, Croatia, The Czech Republic, Hungary, FYR Macedonia, Poland, Romania and Turkey. Sample period: 2008Q1-2017Q1.

In the light of the results provided by the FMOLS methodology and taking account of the fact that the analyzed countries may have been influenced by common shocks on their European integration path, we have decided to go a step further in the analysis and consider the presence of common shocks in the region. We capture the global cycle by employing the VIX Index in the analysis. This index is a measure of the expected range of movements in the S\&P 500 index over the subsequent year. By construction, the VIX is a measure of the market perceived volatility, in either direction (see Appendix 2 for a detailed description). Therefore, 
the interpretation regarding the impact of the index is similar with the one we had with respect to the ESI. The results for our benchmark models are reported in Table $8 a$. The results do not change significantly with respect to the initial ones and the ESI keeps its magnitude and significance, thus confirming the validity of the initial models.

\begin{tabular}{|c|c|c|c|c|c|}
\hline \multicolumn{6}{|c|}{ Table 8- Panel money demand estimations DOLS -robustness check } \\
\hline \multicolumn{3}{|c|}{ a) including the Global cycle } & \multicolumn{3}{|c|}{ b) including Sentix } \\
\hline Dependent variable M2 & Model 1 & Model 2 & Dependent variable M2 & Model 1 & Model 2 \\
\hline $\mathrm{Y}$ & $\begin{array}{l}1.020 * * * \\
(0.000)\end{array}$ & $\begin{array}{l}1.008 * * * \\
(0.000)\end{array}$ & $\mathrm{Y}$ & $\begin{array}{l}1.020 * * * \\
(0.000)\end{array}$ & $\begin{array}{l}1.007 * * * \\
(0.000)\end{array}$ \\
\hline $\mathrm{R}$ & $\begin{array}{l}-0.001 * * * \\
(0.000)\end{array}$ & $\begin{array}{l}-0.001 * * * \\
(0.000)\end{array}$ & $\mathrm{R}$ & $\begin{array}{l}-0.001 * * * \\
(0.000)\end{array}$ & $\begin{array}{l}-0.001 * * * \\
(0.000)\end{array}$ \\
\hline$\Pi$ & $\begin{array}{l}-0.018 * * * \\
(0.000)\end{array}$ & $\begin{array}{l}-0.035 * * * \\
(0.000)\end{array}$ & $\Pi$ & $\begin{array}{l}-0.020 \text { **** } \\
(0.000)\end{array}$ & $\begin{array}{l}-0.036^{* * * *} \\
(0.000)\end{array}$ \\
\hline EX_EUR & $\begin{array}{l}-0.244 * * * \\
(0.000)\end{array}$ & & EX_EUR & $\begin{array}{l}-0.238 * * * \\
(0.000)\end{array}$ & \\
\hline EX_USD & & $\begin{array}{l}-0.209 * * * \\
(0.000)\end{array}$ & EX_USD & & $\begin{array}{l}-0.197 * * * \\
(0.000)\end{array}$ \\
\hline ESI & $\begin{array}{l}-0.385^{* * * *} \\
(0.000)\end{array}$ & $\begin{array}{l}-0.398^{* * *} \\
(0.000)\end{array}$ & SENTIX & $\begin{array}{l}0.003 * * \\
(0.000)\end{array}$ & $\begin{array}{l}0.002 * * * \\
(0.000)\end{array}$ \\
\hline VIX & $\begin{array}{l}-0.002 * * * * \\
(0.003)\end{array}$ & $\begin{array}{l}-0.004 * * * \\
(0.000)\end{array}$ & & & \\
\hline $\mathrm{T}$ & 37 & 37 & $\mathrm{~T}$ & 37 & 37 \\
\hline $\mathrm{N}$ & 264 & 264 & $\mathrm{~N}$ & 264 & 264 \\
\hline
\end{tabular}

Notes: 1$) * * *, * *$ and * denotes significance at $1 \%, 5 \%$ and $10 \%$. 2) Two lags and one lead were included in DOLS first differences. 3) All variables, except the interest rate, are in logs. 4) The panel includes: Bulgaria, Croatia, Czech Republic, Hungary, FYR Macedonia, Poland, Romania, Turkey. Time period: 2008Q1-2017Q1.

Additionally, after performing the robustness tests with respect to the ESI by considering different specifications, we focus our attention on another indicator that can capture the expectations regarding the economic situation. Hence, our variable of interest, the ESI, is replaced with another proxy that translates the impact of economic sentiments, namely the Sentix indicator. This indicator is build based on monthly surveys among 1600 financial analysts and institutional investors who express their opinion regarding the expectations they have for the upcoming six months not only for the Eurozone, but also for the United States, Japan, Asia excluding Japan, Eastern Europe and Latin America.

Therefore, as compared to the ESI, this indicator comprises a narrower segment of the population and makes reference to the expectations regarding the global economy, by including countries from outside Europe. Sentix is constructed as a qualitative diffusionindicator: a high value of this index suggests that the current economic situation is perceived as improving. The results, provided in Table $8 b$, indicate somehow contrasting results to the ESI indicator if we consider strictly the direction in which Sentix influences money demand. 
The traditional determinants of money demand remain in line with the benchmark models. The Sentix indicator, as compared to the ESI, does not indicate the presence of the precautionary effect (which leads to an increase of money demand when expectations deteriorate), but the presence of the substitution effect. The positive value of the Sentix in Model 1 and Model 2 indicates that when investors perceive a deterioration of the current situation, they choose to rebalance their portfolio by increasing the demand for real assets. We should not lose sight of the fact that Sentix captures the perceptions concerning the economic situation of different parts of the world, coming from financial and institutional investors. The latter ones represent a segment of the population that can evaluate economic fluctuations in a more objective manner, given that they work with the financial capital and not with personal money holdings, as it was the case for individual consumers (in the case of ESI). In this context, we can assert that these result do not contradict, but compliment our initial ones as they restate the effect of the perceived uncertainty with respect to different segments of the population.

\section{Conclusions}

The question of the money demand stability has gained renewed interest in the CEECs within the context of the European economic and monetary integration. This paper presents new estimates of the demand for domestic real money in a sample of eight Central and Eastern European countries, using panel data over the time span 2008-2017. The empirical analysis is conducted using panel cointegration techniques: it contributes to the previous empirical money demand literature by assessing the role of sentiments in the domestic demand for money, in addition to the traditional determinants. This is done in a sample that includes the CEECs members of the EU and candidates at the monetary integration, and the CEECs candidates to the European integration.

Following the previous empirical studies on money demand, we start with the traditional formulation of the money demand function that includes a scale variable and opportunity cost variables. Furthermore, trying to capture the particularities of our sample in terms of monetary developments over the period under analysis, the specification of money demand function is extended to include the European sentiment indicator (ESI). This indicator is meant to capture the effects of investors' perceptions from five sectors on the overall stance of the economy. In the specification of the money demand function, this indicator can be considered as a measure of the perceived uncertainty. Given that the CEECs are on their way towards European 
integration (FYR Macedonia and Turkey) or towards monetary integration (Bulgaria, Croatia, the Czech Republic, Hungary, Poland and Romania) we hypothesize that the degree of uncertainty perceived as coming from the European Union or from the euro area, may significantly affect the demand for domestic money.

The results obtained using the panel DOLS estimator applied to the money demand function offer some interesting insights regarding the stability of money demand, when economic agents' perceptions and expectations are considered. The cointegration between real money and its determinants is confirmed regardless of the proxy used for the exchange rate. The income elasticity is around unity and is significant in all of the analyzed cases. The interest rate has small, but negative effects on the demand for money. The same effect is spotted also in the case of inflation rate. This outcome is somehow expected, as the two variables capture the opportunity cost of holding money. The currency substitution effect between the national currencies and foreign currency is confirmed for both bilateral exchange rates -against euro or against the USD- with a smaller coefficient for the latter. As five out of the eight countries in our sample were EU members during the years covered by our analysis, we find a significant currency effect in favor of the euro.

The role of economic sentiments on money demand is found to be significant. The lower the value of the ESI indicator, the greater the perceived uncertainty is. This leads to an increase of money demand due to precautionary reasons. The robustness checks confirm the validity of our findings. The results remain in line with the benchmark models, regardless of the exchange rate proxies that we use. Moreover, when we control for the effects of the global economic and financial crisis of 2008-2010, or for the quantitative easing measures implemented by the European Central Bank or for the impact of the common shocks by means of the global cycle, we obtain similar results. The use of another proxy to capture the perceived economic situation (namely the Sentix) gives us interesting results as compared to the ESI, by restating the effect of the perceived uncertainty with respect to different categories of consumers and investors. In both specifications (the one including the ESI and the one including the Sentix) the empirical results indicate that there is a significant effect of economic sentiments on money demand, be it in terms of precaution or substitution.

Our paper shows that the extended money demand function, which includes variables that capture the assessment of future economic developments, provides an interesting explanation for the behavior of money demand in the Central and Eastern European countries. We 
conclude that the stability of the demand for money is indeed influenced by the changes occurred in the process of integration. Taking into consideration the consumers' and investors' assessment regarding the overall economic activity inside the European Union, helps us identify a stable money demand function.

\section{Acknowledgements}

We would like to thank Ansgar Belke, Jarko Fidrmuc, Claudiu Albulescu and two anonymous referees for constructive remarks and suggestions that helped us improve the paper. Many thanks to the participants at the EEFS 2018 and ERMAS 2018 for insightful comments on a previous version of the paper. 


\section{REFFERENCES}

1. Bahmani-Oskooee, M., Kutan, A. M. and Xi, D. (2013) 'The impact of economic and monetary uncertainty on the demand for money in emerging economies', Applied Economics, 45(23), pp. 3278-3287.

2. Bahmani, S. and Kutan, A. M. (2010) 'How stable is the demand for money in emerging economies ?', Applied Economics, 42, pp. 3307-3318.

3. Beckmann, E., Scheiber, T. and Stix, H. (2011) 'How the Crisis Affected Foreign Currency Borrowing in CESEE: Microeconomic Evidence and Policy Implications', Focus on European Economic Integration, (Q1/11), pp. 25-43.

4. Brown, M. and Stix, H. (2014) 'The Euroization of Bank Deposit in Eastern Europe', Working Papers (Oesterreichische Nationalbank), (197), pp. 1-55.

5. Choi, G. W. and Oh, S. (2003) 'A Money Demand Function with Output Uncertainty, Monetary Uncertainty, and Financial', Journal of Money, Credit and Banking, 35(5), pp. 685-709.

6. Choi, I. (2001) 'Unit root tests for panel data', Journal of International Money and Finance, 20, pp. 249-272.

7. Dreger, C., Reimers, H.-E. and Roffia, B. (2007) 'Long-Run Money Demand in the New EU Member States with Exchange Rate Effects', Eastern European Economics, 45(2), pp. 75-94.

8. Dritsaki, M. and Dritsaki, C. (2012) 'A panel data approach to the demand for money in Bulgaria and Romania', Applied Economics Letters, 19, pp. 705-710.

9. European Central Bank Monthly Bulletin (2011) 'Economic and Monetary Developments', October.

10. Fidrmuc, J. (2009) 'Money demand and disinflation in selected CEECs during the accession to the EU', Applied Economics, 41(10), pp. 1259-1267.

11. Flash Eurobarometer, 453 (2017) Introduction of the euro in the Member States that have not yet adopted the common currency.

12. Friedman, M. (1987) 'Quantity Theory of Money', In The new Palgrave: A dictionary of Economics, edited by John Eatwell, Murray Milgate and Peter Newman, 4, pp. 320.

13. Georgiadis, G. and Mehl, A. (2016) 'Financial globalisation and monetary policy effectiveness', Journal of International Economics, 103(November), pp. 200-212.

14. Gertler, P. and Hofmann, B. (2016) 'Monetary facts revisited', BIS Working Papers, (566).

15. Hsieh, W.-J. and Hsing, Y. (2009) 'Tests of currency substitution, capital mobility and nonlinearity of Hungary's money demand function', Applied Economics Letters, 16, pp. 959-964.

16. Im, K. S., Pesaran, M. H. and Shin, Y. (2003) 'Testing for unit roots in heterogeneous panels', Journal of Econometrics, 115(1), pp. 53-74.

17. IMF (2015) 'Central and Eastern Europe: New Member States (NMS) Policy Forum', International Monetary Fund Country Report, (15/98).

18. IMF (2016) 'Central, Eastern, and Southern Europe: How to Get Back on the Fast Track', Regional Economic Issuesconomic Issues, (May).

19. Kao, C. and Chiang, M.-H. (2000) 'On the estimation and inference of a cointegrated regression in panel data', American Journal of Mathematical and Management Sciences, 15, pp. 179-222.

20. Komárek, L. and Melecky, M. (2004) 'Money Demand in an Open Transition Economy', Eastern European Economics, 42(5), pp. 73-94.

21. Leventakis, J. A. (1993) 'Modelling money demand in open economies over the 
modern floating rate period', Applied Economics, 25, pp. 1005-1012.

22. Levin, A., Lin, C.-F. and Chu, C.-S. J. (2002) 'Unit Root Tests in Panel Data: Asymptotic and Finite Sample Properties', Journal of Econometrics, 108, pp. 1-24.

23. Levy-Yeyati, E. and Rey, H. (2006) 'Financial Dollarisation: Evaluating the Consequences', Economic Policy, 21(45), pp. 61-118.

24. Ma, Y. and Lin, X. (2016) 'Financial development and the effectiveness of monetary policy', Journal of Banking and Finance. Elsevier B.V., 68, pp. 1-11.

25. Maddala, G. S. and Wu, S. (1999) 'A Comparative Study of Unit Root Tests with Panel Data and A New Simple Test', Oxford Bulletin of Economics and Statistics, 61(Special), pp. 631-652.

26. Mark, N. C. and Sul, D. (2003) 'Cointegration Vector Estimation by Panel DOLS and Long-run Money Demand', Oxford Bulletin of Economics and Statistics, 65(5), pp. 655-680.

27. Moder, I. (2017) 'Spillovers from the ECB' s non-standard monetary policy measures on south-eastern Europe', European Central Bank Working Paper Series, (2095).

28. Neal, T. (2014) 'Panel cointegration analysis with xtpedroni', The Stata Journal, 14(3), pp. 684-692.

29. Oros, C. and Romocea-Turcu, C. (2009) 'The Monetary Transmission Mechanisms in the CEECs: A Structural VAR Approach', Applied Econometrics and International Development, $9(2)$.

30. Pedroni, P. (1999) 'Critical values for cointegration tests in heterogeneous panels with multiple regressors', Oxford Bulletin of Economics and Statistics, 61, pp. 653-670.

31. Pedroni, P. (2000) 'Fully Modified OLS for Heterogeneous Cointegrated Panels', Advances in Econometrics, 15, pp. 93-130.

32. Pedroni, P. (2004) 'Panel Cointegration: Asymptotic and Finite Sample Properties of Pooled Time Series Tests With an Application to the PPP Hypothesis', Econometric Theory, 20, pp. 597-625.

33. Pesaran, M. H. (2004) 'General Diagnostic Tests for Cross Section Dependence in Panels', (IZA DP1240).

34. Phillips, P. C. B. and Moon, H. R. (1999) 'Linear Regression Limit Theory for Nonstationary Panel Data', Econometrica, 67(5), pp. 1057-1111.

35. Saikkonen, P. (1991) 'Asymptotically Efficient Estimation of Cointegration Regressions', Econometric Theory, 7(1), pp. 1-21.

36. Selçuk, F. (2003) 'Currency substitution: new evidence from emerging economies', Economic Letters, 78(2), pp. 219-224.

37. Škare, M., Benazic, M. and Tomic, D. (2016) 'On the Neutrality of Money in CEE (EU members) States : A Panel Cointegration Analysis', Acta Oeconomica, 66(3), pp. 393-418.

38. Sriram, S. S. (1999) 'Survey of Literature on Demand for Money: Theoretical and Empirical Work with Special Reference to Error-Correction Models', IMF Working Papers, 99(64).

39. Stock, J. H. and Watson, M. W. (1993) 'A Simple Estimator of Cointegrating Vectors in Higher Order Integrated Systems', Econometrica, 61(4), pp. 783-820.

40. Vladova, Z. and Yanchev, M. (2015) 'Empirical Evidence on the Relationship between Money Supply Dynamics and Prices in Bulgaria', Bulgarian National Bank, DP/100/201(November). 
Appendix 1- CEECs classification (IMF)

\begin{tabular}{|c|c|c|c|}
\hline Main group & Group & Country & $\begin{array}{l}\text { Country } \\
\text { code }\end{array}$ \\
\hline \multirow[t]{2}{*}{$\begin{array}{c}\text { CESEE-Central, } \\
\text { Eastern and } \\
\text { Southeastern Europe }\end{array}$} & $\begin{array}{l}\text { European Union countries } \\
\text { (EU) }\end{array}$ & $\begin{array}{l}\text { Bulgaria } \\
\text { Croatia } \\
\text { Czech Republic } \\
\text { Hungary } \\
\text { Poland } \\
\text { Romania }\end{array}$ & $\begin{array}{l}\text { BGR } \\
\text { HRV } \\
\text { CZE } \\
\text { HUN } \\
\text { POL } \\
\text { ROU }\end{array}$ \\
\hline & $\begin{array}{l}\text { Non-European Union countries } \\
\text { (Non-EU) }\end{array}$ & $\begin{array}{l}\text { Macedonia, FYR } \\
\text { Turkey }\end{array}$ & $\begin{array}{l}\text { MKD } \\
\text { TUR }\end{array}$ \\
\hline
\end{tabular}

Source: International Monetary Fund classification (for a detailed classification see: IMF (2016)) 
Appendix 2- Variables description and data sources

\begin{tabular}{|c|c|c|c|c|}
\hline Variable & Full name & Definition & Units & Source \\
\hline M2 & $\begin{array}{l}\text { Log of } \mathrm{M} 2 \\
\text { monetary } \\
\text { aggregate }\end{array}$ & $\begin{array}{l}\text { Real monetary aggregate } \mathrm{M} 2^{\mathrm{a}} \text { : the nominal } \\
\text { monetary aggregates (national definitions) were } \\
\text { deflated by Consumer Price Index CPI (index } \\
2010=100 \% \text { ); *For Montenegro annual data is } \\
\text { extracted for Broad money (constant LCU) from } \\
\text { World Bank. }\end{array}$ & $\begin{array}{l}\text { Millions of } \\
\text { national } \\
\text { currency } \\
\text { (constant prices, } \\
2010=100 \% \text { ) }\end{array}$ & $\begin{array}{l}\text { IFS, World } \\
\text { Bank }\end{array}$ \\
\hline $\mathrm{Y}$ & Log of real GDP & $\begin{array}{l}\text { Gross Domestic Product, Real }^{\mathrm{a}} \\
\text { Gross domestic product at market prices, } \\
\text { Chained linked volumes (2010), million units of } \\
\text { national currency, Unadjusted data (i.e. neither } \\
\text { seasonally adjusted nor calendar adjusted). }\end{array}$ & $\begin{array}{l}\text { Chained linked } \\
\text { volumes (2010), } \\
\text { million units of } \\
\text { national } \\
\text { currency }\end{array}$ & Eurostat \\
\hline$\Pi$ & Inflation rate & $\begin{array}{l}\text { This variable is defined as the rate of growth of } \\
\text { CPI, where CPI is the Consumer Price Index } \\
\text { (Index 2010=100\%). }\end{array}$ & $\begin{array}{c}\text { Percent } \\
(2010=100 \%)\end{array}$ & IFS \\
\hline $\mathrm{R}$ & Interest rate & Deposit rate & $\begin{array}{l}\text { Percent per } \\
\text { annum }\end{array}$ & IFS \\
\hline EX_NEER & $\begin{array}{l}\text { Log of Nominal } \\
\text { Effective } \\
\text { Exchange Rate }\end{array}$ & $\begin{array}{l}\text { Nominal Effective Exchange Rate, Trade } \\
\text { Partners by Consumer Price Index. An increase } \\
\text { in this variable reflects appreciation of domestic } \\
\text { currency against the weighted basket of } \\
\text { currencies of its trading partners. }\end{array}$ & $\begin{array}{c}\text { Index } \\
(2010=100 \%)\end{array}$ & IFS \\
\hline EX_REER & $\begin{array}{l}\text { Log of Real } \\
\text { Effective } \\
\text { Exchange Rate }\end{array}$ & $\begin{array}{l}\text { Real Effective Exchange Rate, Trade Partners } \\
\text { by Consumer Price Index. An increase in this } \\
\text { variable reflects appreciation of domestic } \\
\text { currency against the weighted basket of } \\
\text { currencies of its trading partners. }\end{array}$ & $\begin{array}{c}\text { Index } \\
(2010=100 \%)\end{array}$ & IFS \\
\hline EX_EUR & $\begin{array}{l}\text { Nominal } \\
\text { exchange rate } \\
\text { against EUR }\end{array}$ & Euro/ECU exchange rates - quarterly data & $\begin{array}{l}\text { National } \\
\text { currency, } \\
\text { Average }\end{array}$ & Eurostat \\
\hline EX_USD & $\begin{array}{l}\text { Nominal } \\
\text { exchange rate } \\
\text { against USD }\end{array}$ & $\begin{array}{l}\text { National Currency per US Dollar, Period } \\
\text { Average }\end{array}$ & Rate & IFS \\
\hline ESI & $\begin{array}{l}\text { Log of European } \\
\text { Sentiment } \\
\text { Indicator }\end{array}$ & $\begin{array}{l}\text { The European sentiment indicator (ESI) is } \\
\text { computed as a weighted average of the balances } \\
\text { of selected questions in five sectors surveys } \\
\text { covered by the EU Business and Consumer } \\
\text { Surveys Programme. The sectors are industry } \\
\text { (weight } 40 \%) \text {, services ( } 30 \%) \text {, consumers } \\
(20 \%) \text {, retail (5\%) and construction (5\%). } \\
\text { Seasonally adjusted data, not calendar adjusted } \\
\text { data. }\end{array}$ & Index & Eurostat \\
\hline VIX & VIX Index & $\begin{array}{l}\text { The VIX Index measures the level of expected } \\
\text { volatility of the S\&P } 500 \text { Index over the next } 30 \\
\text { days that is implied in the bid/ask quotations of } \\
\text { SPX options. The VIX Index is forward looking } \\
\text { and seeks to predict the variability of future } \\
\text { market movements. }\end{array}$ & Index & $\begin{array}{l}\text { http://www } \\
\text { cboe.com }\end{array}$ \\
\hline SENTIX & $\begin{array}{lr}\text { Eastern } & \text { Europe, } \\
\text { Business } & \text { Surveys, } \\
\text { Sentix } \quad \text { (current } \\
\text { situation) }\end{array}$ & $\begin{array}{l}\text { The Sentix sentiment indicator is a monthly } \\
\text { survey among } 1600 \text { financial analysts and } \\
\text { institutional investors. Participants are asked } \\
\text { about their opinion regarding the current } \\
\text { economic situation and their expectations for } \\
\text { the next six months in the Eurozone, United } \\
\text { States, Japan, Asia excl Japan, Eastern Europe } \\
\text { and Latin America. The Sentix sentiment } \\
\text { indicator consists of } 36 \text { different indicators. }\end{array}$ & $\begin{array}{l}\text { qualitative } \\
\text { diffusion- } \\
\text { indicator }\end{array}$ & $\begin{array}{l}\text { Datastream } \\
\text { Thompson } \\
\text { Reuters }\end{array}$ \\
\hline
\end{tabular}

Note: ${ }^{a}$ ) For the real monetary aggregate and real GDP the series were seasonally adjusted before estimation. 
Appendix 3- Monetary and exchange rate regimes (as of October 2017)

\begin{tabular}{|c|c|c|c|c|c|c|}
\hline Country & $\begin{array}{l}\text { Country } \\
\text { code }\end{array}$ & Currency & $\begin{array}{l}\text { EU or EA } \\
\text { member } \\
\text { since... }\end{array}$ & $\begin{array}{l}\text { Monetary } \\
\text { regime }\end{array}$ & policy & $\begin{array}{l}\text { Exchange } \\
\text { rate } \\
\text { regime }\end{array}$ \\
\hline
\end{tabular}

\begin{tabular}{|c|c|c|c|c|c|}
\hline \multicolumn{6}{|c|}{ European Union member countries $(\mathbf{E U})$} \\
\hline BULGARIA & BGR & $\begin{array}{l}\text { Bulgarian } \\
\text { Lev (BGN) }\end{array}$ & 01.01 .2007 & $\begin{array}{l}\text { Currency board arrangement } \\
\text { (since 1997); The Bulgarian } \\
\text { LEV does not participate to } \\
\text { ERM II; }\end{array}$ & $\begin{array}{l}\text { fixed- } \\
\text { currency } \\
\text { board to euro } \\
\text { (1.95583 levs } \\
\text { per euro) }\end{array}$ \\
\hline CROATIA & HRV & $\begin{array}{l}\text { Croatian } \\
\text { Kuna } \\
\text { (HRK) }\end{array}$ & 01.07 .2013 & $\begin{array}{l}\text { Nominal exchange rate of the } \\
\text { Kuna against the euro; The } \\
\text { Croatian Kuna does not } \\
\text { participate to ERM II; }\end{array}$ & $\begin{array}{l}\text { managed- } \\
\text { crawl-like } \\
\text { arrangement } \\
\text { EUR }\end{array}$ \\
\hline $\begin{array}{l}\text { CZECH } \\
\text { REPUBLIC }\end{array}$ & CZE & $\begin{array}{l}\text { Czech } \\
\text { Koruna } \\
\text { (CZK) }\end{array}$ & 01.05 .2004 & $\begin{array}{l}\text { Direct inflation targeting } \\
\text { (since 1998); }\end{array}$ & $\begin{array}{l}\text { residual- } \\
\text { other } \\
\text { managed } \\
\text { arrangement }\end{array}$ \\
\hline HUNGARY & HUN & $\begin{array}{l}\text { Hungarian } \\
\text { Forint } \\
\text { (HUF) }\end{array}$ & 01.05 .2004 & $\begin{array}{l}\text { Inflation targeting system } \\
\text { (since 2001); The Hungarian } \\
\text { Forint does not participate to } \\
\text { ERM II; }\end{array}$ & floating \\
\hline POLAND & POL & $\begin{array}{l}\text { Polish Zloty } \\
\text { (PLN) }\end{array}$ & 01.05 .2004 & $\begin{array}{l}\text { Direct inflation targeting } \\
\text { (since 1998); The Polish } \\
\text { Zloty does not participate to } \\
\text { ERM II; }\end{array}$ & floating \\
\hline ROMANIA & ROU & $\begin{array}{l}\text { Romanian } \\
\text { Leu (RON) }\end{array}$ & 01.01 .2007 & $\begin{array}{l}\text { Direct inflation targeting } \\
\text { (since 2005); The Romanian } \\
\text { Leu does not participate to } \\
\text { ERM II; }\end{array}$ & floating \\
\hline
\end{tabular}

\begin{tabular}{|c|c|c|c|c|c|}
\hline \multicolumn{6}{|c|}{ European Union official candidate countries (non-EU) } \\
\hline $\begin{array}{l}\text { FYR } \\
\text { MACEDONIA }\end{array}$ & MKD & $\begin{array}{l}\text { Macedonian } \\
\text { Denar } \\
(\mathrm{MKD})\end{array}$ & $\mathrm{n} / \mathrm{a}$ & $\begin{array}{l}\text { Nominal exchange rate } \\
\text { targeting against euro (since } \\
2002 \text { ) }\end{array}$ & $\begin{array}{l}\text { managed- } \\
\text { stabilized } \\
\text { arrangement } \\
\text { (EUR) }\end{array}$ \\
\hline TURKEY & TUR & $\begin{array}{l}\text { Turkish } \\
\text { Lira (TRY) }\end{array}$ & $\mathrm{n} / \mathrm{a}$ & $\begin{array}{l}\text { Inflation targeting } \text { (since } \\
\text { 2002) }\end{array}$ & floating \\
\hline
\end{tabular}

Source: authors' computation based on data from the sites of the National Banks and Thomson Reuters (for the exchange rates regimes) 
Appendix 4- Panel unit root tests

\begin{tabular}{|c|c|c|c|c|c|c|c|c|}
\hline $\begin{array}{l}\text { Variable } \\
\text { name }\end{array}$ & IPS-test & IPS $^{T}$-test & $\begin{array}{l}\text { ADF- } \\
\text { Fisher } \\
\text { test }\end{array}$ & $\begin{array}{l}\text { ADF- } \\
\text { Fisher }^{\mathrm{T}} \\
\text { test }\end{array}$ & $\begin{array}{l}\text { PP-Fisher } \\
\text { test }\end{array}$ & $\begin{array}{l}\text { PP- } \\
\text { Fisher } \\
\text { test }\end{array}$ & LLC & $\mathbf{L L C}^{\mathrm{T}}$ \\
\hline \multicolumn{9}{|l|}{ 1. Levels } \\
\hline M2 & $\begin{array}{l}-1.718 \\
(0.042)^{* *}\end{array}$ & $\begin{array}{l}-1.177 \\
(0.119)\end{array}$ & $\begin{array}{l}61.746 \\
(0.000)^{* * *}\end{array}$ & $\begin{array}{l}5.864 \\
(0.989) \\
\end{array}$ & $\begin{array}{l}25.236 \\
(0.065)^{*}\end{array}$ & $\begin{array}{l}25.830 \\
(0.056)^{*}\end{array}$ & $\begin{array}{l}3.172 \\
(0.999) \\
\end{array}$ & $\begin{array}{l}0.160 \\
(0.563)\end{array}$ \\
\hline $\mathrm{Y}$ & $\begin{array}{l}-2.523 \\
(0.005)^{* * *}\end{array}$ & $\begin{array}{l}-0.534 \\
(0.296) \\
\end{array}$ & $\begin{array}{l}59.591 \\
(0.000) * * *\end{array}$ & $\begin{array}{l}5.896 \\
(0.989) \\
\end{array}$ & $\begin{array}{l}59.546 \\
(0.000)^{* * *}\end{array}$ & $\begin{array}{l}37.194 \\
(0.002) * * *\end{array}$ & $\begin{array}{l}.319 \\
(0.989) \\
\end{array}$ & $\begin{array}{l}-2.820 \\
(0.002) * * *\end{array}$ \\
\hline$\pi$ & $\begin{array}{l}-12.248 \\
(0.000)^{* * *}\end{array}$ & $\begin{array}{l}-16.845 \\
(0.000)^{* * *}\end{array}$ & $\begin{array}{l}72.435 \\
(0.000)^{* * *}\end{array}$ & $\begin{array}{l}54.795 \\
(0.000) * * *\end{array}$ & $\begin{array}{l}271.479 \\
(0.000)^{* * *}\end{array}$ & $\begin{array}{l}266.938 \\
(0.000)^{* * *}\end{array}$ & $\begin{array}{l}-0.868 \\
(0.192) \\
\end{array}$ & $\begin{array}{l}-0.023 \\
(0.490) \\
\end{array}$ \\
\hline $\mathrm{R}$ & $\begin{array}{l}2.059 \\
(0.980)\end{array}$ & $\begin{array}{l}-0.973 \\
(0.165)\end{array}$ & $\begin{array}{l}35.740 \\
(0.003)^{* * *}\end{array}$ & $\begin{array}{l}15.465 \\
(0.490)\end{array}$ & & $\begin{array}{l}16.060 \\
(0.448)\end{array}$ & $\begin{array}{l}0.975 \\
(0.835)\end{array}$ & $\begin{array}{l}-2.744 \\
(0.003) * * *\end{array}$ \\
\hline EX_EUR & $\begin{array}{l}-3.349 \\
(0.000)^{* * *}\end{array}$ & $\begin{array}{l}-4.593 \\
(0.000)^{* * *}\end{array}$ & $\begin{array}{l}33.107 \\
(0.007) * * *\end{array}$ & $\begin{array}{l}75.594 \\
(0.000) * * *\end{array}$ & $\begin{array}{l}41.227 \\
(0.000) * * *\end{array}$ & $\begin{array}{l}48.359 \\
(0.000) * * *\end{array}$ & $\begin{array}{l}0.082 \\
(0.532) \\
\end{array}$ & \\
\hline EX_USD & $\begin{array}{l}-1.936 \\
(0.026)^{* *}\end{array}$ & $\begin{array}{l}-4.418 \\
(0.000)^{* * *}\end{array}$ & $\begin{array}{l}22.424 \\
(0.130) \\
\end{array}$ & $\begin{array}{l}7.638 \\
(0.958)\end{array}$ & $\begin{array}{l}29.161 \\
(0.022)^{* *}\end{array}$ & $\begin{array}{l}33.324 \\
(0.006) * * *\end{array}$ & $\begin{array}{l}1.824 \\
(0.965) \\
\end{array}$ & $\begin{array}{l}-4.646 \\
(0.000)^{* * *}\end{array}$ \\
\hline EX_NEER & $\begin{array}{l}-0.963 \\
(0.167) \\
\end{array}$ & $\begin{array}{l}-5.088 \\
(0.000)^{* * *}\end{array}$ & $\begin{array}{l}25.206 \\
(0.066)^{*}\end{array}$ & $\begin{array}{l}25.222 \\
(0.066)^{*}\end{array}$ & $\begin{array}{l}13.413 \\
(0.642) \\
\end{array}$ & $\begin{array}{l}17.803 \\
(0.335)\end{array}$ & $\begin{array}{l}2.079 \\
(0.981) \\
\end{array}$ & $\begin{array}{l}-2.881 \\
(0.002) * * *\end{array}$ \\
\hline EX_REER & $\begin{array}{l}-4.326 \\
(0.000) * * *\end{array}$ & $\begin{array}{l}-4.947 \\
(0.000)^{* * *}\end{array}$ & $\begin{array}{l}39.790 \\
(0.000)^{* * *}\end{array}$ & $\begin{array}{l}42.655 \\
(0.000) * * *\end{array}$ & $\begin{array}{l}25.589 \\
(0.060) *\end{array}$ & $\begin{array}{l}23.351 \\
(0.104) \\
\end{array}$ & $\begin{array}{l}-0.300 \\
(0.381) \\
\end{array}$ & $\begin{array}{l}-3.857 \\
(0.000)^{* * *}\end{array}$ \\
\hline ESI & $\begin{array}{l}2.027 \\
(0.021)^{* *}\end{array}$ & $\begin{array}{l}-0.941 \\
(0.173) \\
\end{array}$ & $\begin{array}{l}71.463 \\
(0.000)^{* * * *}\end{array}$ & $\begin{array}{l}80.097 \\
(0.000) * * *\end{array}$ & $\begin{array}{l}19.364 \\
(0.250)\end{array}$ & $\begin{array}{l}10.796 \\
(0.821)\end{array}$ & $\begin{array}{l}-2.458 \\
(0.007) * * *\end{array}$ & $\begin{array}{l}-6.736 \\
(0.000)^{* * *}\end{array}$ \\
\hline $\begin{array}{l}\text { Variable } \\
\text { name }\end{array}$ & IPS-test & IPS $^{\mathrm{T}}$-test & $\begin{array}{l}\text { ADF- } \\
\text { Fisher } \\
\text { test }\end{array}$ & $\begin{array}{l}\text { ADF- } \\
\text { Fisher } \\
\text { test }\end{array}$ & $\begin{array}{l}\text { PP-Fisher } \\
\text { test }\end{array}$ & $\begin{array}{l}\text { PP- } \\
\text { Fisher } \\
\text { test }\end{array}$ & LLC & $\mathbf{L L C}^{\mathrm{T}}$ \\
\hline \multicolumn{9}{|l|}{ 2. First diff } \\
\hline M2 & $\begin{array}{l}-11.050 \\
(0.000)^{* * *}\end{array}$ & $\begin{array}{l}-10.166 \\
(0.000)^{* * *}\end{array}$ & $\begin{array}{l}90.131 \\
(0.000)^{* * *}\end{array}$ & $\begin{array}{l}49.455 \\
(0.000) * * *\end{array}$ & $\begin{array}{l}193.517 \\
(0.000)^{* * *}\end{array}$ & $\begin{array}{l}163.352 \\
(0.000)^{* * *}\end{array}$ & $\begin{array}{l}-6.602 \\
(0.000) * * *\end{array}$ & $\begin{array}{l}-6.349 \\
(0.000) * * *\end{array}$ \\
\hline $\mathrm{Y}$ & $\begin{array}{l}-13.885 \\
(0.000)^{* * *}\end{array}$ & $\begin{array}{l}-16.340 \\
(0.000)^{* * *}\end{array}$ & $\begin{array}{l}77.207 \\
(0.000)^{* * *}\end{array}$ & $\begin{array}{l}36.507 \\
(0.002) * * *\end{array}$ & $\begin{array}{l}362.513 \\
(0.000)^{* * *}\end{array}$ & $\begin{array}{l}382.041 \\
(0.000)^{* * * *}\end{array}$ & $\begin{array}{l}-8.086 \\
(0.000) * * *\end{array}$ & $\begin{array}{l}-10.152 \\
(0.000)^{* * *}\end{array}$ \\
\hline$\pi$ & $\begin{array}{l}-26.098 \\
(0.000)^{* * *}\end{array}$ & $\begin{array}{l}-25.409 \\
(0.000)^{* * *}\end{array}$ & $\begin{array}{l}128.992 \\
(0.000)^{* * *}\end{array}$ & $\begin{array}{l}70.176 \\
(0.000)^{* * *}\end{array}$ & $\begin{array}{l}554.948 \\
(0.000)^{* * *}\end{array}$ & $\begin{array}{l}535.904 \\
(0.000)^{* * *}\end{array}$ & $\begin{array}{l}-5.998 \\
(0.000) * * *\end{array}$ & $\begin{array}{l}-3.092 \\
(0.001) * * *\end{array}$ \\
\hline $\mathrm{R}$ & $\begin{array}{l}-11.474 \\
(0.000)^{* * *}\end{array}$ & $\begin{array}{l}-10.291 \\
(0.000)^{* * *}\end{array}$ & $\begin{array}{l}92.437 \\
(0.000) * * *\end{array}$ & $\begin{array}{l}54.352 \\
(0.000)^{* * *}\end{array}$ & $\begin{array}{l}227.765 \\
(0.000)^{* * *}\end{array}$ & $\begin{array}{l}194.031 \\
(0.000)^{* * *}\end{array}$ & $\begin{array}{l}-6.225 \\
(0.000) * * *\end{array}$ & $\begin{array}{l}-4.706 \\
(0.000) * * *\end{array}$ \\
\hline EX_EUR & $\begin{array}{l}-13.601 \\
(0.000)^{* * *}\end{array}$ & $\begin{array}{l}-12.242 \\
(0.000)^{* * *}\end{array}$ & $\begin{array}{l}116.206 \\
(0.000) * * *\end{array}$ & $\begin{array}{l}59.841 \\
(0.000)^{* * *}\end{array}$ & $\begin{array}{l}344.269 \\
(0.000)^{* * *}\end{array}$ & $\begin{array}{l}301.759 \\
(0.000)^{* * *}\end{array}$ & $\begin{array}{l}-14.285 \\
(0.000)^{* * *}\end{array}$ & $\begin{array}{l}-8.641 \\
(0.000)^{* * *}\end{array}$ \\
\hline EX_USD & $\begin{array}{l}-15.974 \\
(0.000)^{* * *}\end{array}$ & $\begin{array}{l}-13.532 \\
(0.000)^{* * *}\end{array}$ & $\begin{array}{l}116.008 \\
(0.000)^{* * *}\end{array}$ & $\begin{array}{l}63.709 \\
(0.000)^{* * *}\end{array}$ & $\begin{array}{l}352.865 \\
(0.000)^{* * *}\end{array}$ & $\begin{array}{l}319.193 \\
(0.000) * * *\end{array}$ & $\begin{array}{l}-10.451 \\
(0.000)^{* * *}\end{array}$ & $\begin{array}{l}-8.483 \\
(0.000)^{* * *}\end{array}$ \\
\hline EX_NEER & $\begin{array}{l}-12.519 \\
(0.000)^{* * *}\end{array}$ & $\begin{array}{l}-11.751 \\
(0.000)^{* * *}\end{array}$ & $\begin{array}{l}113.004 \\
(0.000) * * *\end{array}$ & $\begin{array}{l}72.148 \\
(0.000) * * *\end{array}$ & $\begin{array}{l}182.798 \\
(0.000)^{* * *}\end{array}$ & $\begin{array}{l}157.818 \\
(0.000) * * *\end{array}$ & $\begin{array}{l}10.335 \\
(0.000)^{* * * *}\end{array}$ & $\begin{array}{l}-6.490 \\
(0.000)^{* * *}\end{array}$ \\
\hline EX_REER & $\begin{array}{l}-13.489 \\
(0.000)^{* * *}\end{array}$ & $\begin{array}{l}-12.272 \\
(0.000)^{* * *}\end{array}$ & $\begin{array}{l}101.827 \\
(0.000) * * *\end{array}$ & $\begin{array}{l}53.471 \\
(0.000) * * *\end{array}$ & $\begin{array}{l}193.307 \\
(0.000)^{* * *}\end{array}$ & $\begin{array}{l}152.556 \\
(0.000)^{* * *}\end{array}$ & $\begin{array}{l}-8.714 \\
(0.000) * * *\end{array}$ & $\begin{array}{l}-7.256 \\
(0.000)^{* * *}\end{array}$ \\
\hline ESI & $\begin{array}{l}11.729 \\
(0.000)^{* * *}\end{array}$ & $\begin{array}{l}-10.388 \\
(0.000)^{* * *}\end{array}$ & $\begin{array}{l}98.862 \\
(0.000)^{* * *}\end{array}$ & $\begin{array}{l}44.931 \\
(0.000) * * *\end{array}$ & $\begin{array}{l}191.995 \\
(0.000)^{* * *}\end{array}$ & $\begin{array}{l}167.269 \\
(0.000)^{* * *}\end{array}$ & $\begin{array}{l}-9.457 \\
(0.000)^{* * *}\end{array}$ & $\begin{array}{l}-8.739 \\
(0.000) * * *\end{array}$ \\
\hline
\end{tabular}

Notes: 1) $* * *, * *$ and $*$ reject the null of unit root at $1 \%, 5 \%$ and $10 \% .2) \operatorname{IPS}^{\mathrm{T}}$, Fisher $^{\mathrm{T}}, \mathrm{LLC}^{\mathrm{T}}$ denotes that a time trend is included. 3) For the IPS-test the W t-bar is reported. 4) For Fisher type tests the inverse chi-squared (p) is reported. 5) For IPS test the number of lags is chosen by AIC, for Fisher test we used 4 lags. 6) The panel includes: Bulgaria, Croatia, The Czech Republic, Hungary, FYR Macedonia, Poland, Romania and Turkey. 